\title{
ASSESSMENT OF ECONOMIC LIFE OF FIREFIGHTING AND RESCUE APPLIANCES BASED ON CHASSIS RENAULT MIDLUM IN THE ZLIN REGION
}

This paper is focused on the evaluation of economic data obtained from operational records of fire-fighting equipment with a focus on Firefighting and Rescue Appliance type of vehicles, especially on exit vehicles based on the chassis Renault Midlum, during the period 2006 - 2013. These vehicles were operated by professional units of the Fire and Rescue Service of the Zlin Region. The paper's aim is to specify the optimum lifetime of the fire-fighting vehicles by the marginal analysis of fire-fighting vehicles' economical operation. Theoretic calculations of the optimum lifetime have been processed with implementing both the method of exponential trends, and Brown method. The residual value of vehicles has been calculated both according to the current Czech tax law, and to the Expert Standard Valuation of motor vehicles in force in the Czech Republic.

Keywords: Acquisition value; costs; amortization; residual value; economic life.

\section{Introduction}

This paper follows on previous publications of the author focused on the functional reliability assessment of Firefighting and Rescue Appliances based on the chassis Renault Midlum [1, 2 and 3]. These vehicles were deployed at professional units of the Fire and Rescue Service of the Zlin Region during the reporting period. Results of alternative calculations of theoretical economic lifetime are presented in this paper.

\section{Characteristics of observed Firefighting and Rescue} Appliances

Key operational and economic characteristics of the monitored equipment for the period 2005-2013 are given in Table 1. Basic tactical and technical characteristics of vehicles type Renault Midlum 270.14 P 4x4, for example, can be traced in the literature [3 and 4].

Basic characteristics of referred vehicles during years 2005-2013

Table 1

\begin{tabular}{|l|r|r|r|r|r|r|r|}
\hline $\begin{array}{c}\text { Vehicle } \\
\text { dislocation }\end{array}$ & $\begin{array}{c}\text { Registration } \\
\text { mark }\end{array}$ & $\begin{array}{c}\text { Date of } \\
\text { commissioning }\end{array}$ & $\begin{array}{c}\text { Purchase } \\
\text { price [CZK] }\end{array}$ & $\begin{array}{c}\text { Mileage } \\
{[\mathrm{km}]}\end{array}$ & $\begin{array}{c}\text { Machine } \\
\text { work at the } \\
\text { site [hour] }\end{array}$ & $\begin{array}{c}\text { Amount of } \\
\text { fuel [litr] }\end{array}$ & $\begin{array}{c}\text { Repair costs } \\
{[\mathrm{CZK}]}\end{array}$ \\
\hline Zlin & $2 Z 78478$ & $20 / 09 / 2006$ & 5805200 & 31278 & 328 & 7264 & 304644 \\
\hline Zlin & $3 Z 34693$ & $17 / 12 / 2007$ & 5000000 & 23490 & 112 & 4561 & 201366 \\
\hline Slavicin & $3 Z 57550$ & $16 / 12 / 2008$ & 5000000 & 9993 & 223 & 3868 & 97669 \\
\hline Otrokovice & $2 Z 78479$ & $20 / 09 / 2006$ & 5805200 & 22860 & 407 & 6632 & 331197 \\
\hline Valasske Mezirici & $2 Z 62647$ & $20 / 02 / 2006$ & 5805200 & 39260 & 670 & 8141 & 369931 \\
\hline Valasske Mezirici & $3 Z 57540$ & $17 / 12 / 2008$ & 5000000 & 10241 & 97 & 3721 & 99661 \\
\hline Valasske Mezirici & $3 Z 34692$ & $14 / 12 / 2007$ & 5000000 & 14618 & 96 & 2856 & 209404 \\
\hline Uhersky Brod & $3 Z 23957$ & $30 / 12 / 2007$ & 5307400 & 28908 & 479 & 9314 & 211802 \\
\hline Uherske Hradiste & $3 Z 66297$ & $05 / 01 / 2009$ & 5307400 & 15584 & 415 & 6780 & 213246 \\
\hline
\end{tabular}

\footnotetext{
* ${ }^{1}$ Ladislav Janosik, ${ }^{2}$ Ivana Janosikova, ${ }^{1}$ Pavel Polednak

${ }^{1}$ Faculty of Safety Engineering, VSB - Technical University of Ostrava, Czech Republic

${ }^{2}$ Faculty of Economics, VSB - Technical University of Ostrava, Czech Republic

Email: ladislav.janosik@vsb.cz
} 


\section{Methods}

Primary operating data [5] for the years 2010-2013 received from the information system IKIS II, were exported to Excel file format and used for failure rate of monitored vehicles evaluating. Data for the years 2005 to 2009 were investigated by the author personally from machinery service records at individual Regional Departments of the Zlin region.

Service life is the ability of the technical system to perform desired functions in order to achieve the ultimate state [6]. Economic life of the vehicle can be generally characterized as reaching the limit state when further operation is economically unsustainable [7].

The economic efficiency of the investment is calculated to assess the economic life of the technical system in the business environment. This procedure would be relatively difficult to apply for the evaluation of firefighting appliances. The methodology of these calculations is based on the input data extremely difficult to define in the sphere of public service [8 and 9]. Expected annual returns and/or annual operating costs in dealing with accidental incidents are representatives of these data. Revenues are primarily represented by preserved properties during the liquidation of accidents. Property owners and insurance companies usually have different views on the amount of damages. Forensic expert opinion and/or the court proceedings decide in these disputes thereafter. The total amount of investment, bank loans, the tax rate for the calculation of investment income taxes and annual depreciation might be examples of detectable data. Further reason for the impossibility of using this calculation method is the requirement of the initial setting of the technical system's lifetime. The approximate lifetime can be only theoretically assumed from the Machinery Service Order [10].

Therefore, the calculation of the monitored vehicles' economic life was performed by use of two simple and generally known methods, both exponential trends method, and the Brown method [11 and 12]. Calculations according to both methods were performed for 5-year operation time period. The residual value of appliances, which is one of data used for calculations, was variously calculated according to the Act No. 586/1992 Coll. on Income Taxes [13], and according to the Expert Standard No. I/2005 - Valuation of motor vehicles [14].

\subsection{Exponential trend method}

The exponential trends method is based on the theoretical assumption that the value of firefighting appliances in time $N_{p}(t)$ has the shape of downward sloping exponential curve [11]. The curve is defined by the equation:

$N_{p}(t)=C \cdot e^{-\alpha \cdot t}$
Similarly, we can define by using an upward sloping exponential curve the trend of costs for maintenance and repairs $N_{u}(t)$ according to the equation:

$N_{u}(t)=A \cdot e^{\beta \cdot t}$

The total value of firefighting appliances $N_{c}(t)$ is a sum of equations (1) a (2):

$N_{c}(t)=C \cdot e^{-\alpha \cdot t}+A \cdot e^{\beta \cdot t}$

Further, we can count the local extreme of the function (3) by derivation. The local extreme $\left(N_{c}(t)\right.$ minimum in this case) represents the optimal time $T_{\text {opt }}$ for replacing the appliance:

$T_{\text {opt }}=\frac{1}{\alpha+\beta} \cdot \ln \left(\frac{\alpha \cdot C}{\beta \cdot A}\right)$

After reaching the minimum point the function $N_{c}(t)$ rises, due to declining price of the firefighting vehicle $N_{c}(t)$ and increasing maintenance and repair costs $N_{u}(t)$. The constants $A$, $C$ and exponent coefficients $\alpha, \beta$ are obtained after processing the input of economic data, building charts and drawing or exponential curve of these charts by using appropriate software, e.g. MS Excel.

\subsection{Brown method}

This method was first published over 55 years ago in the journal Railway Age, in Brown's paper "What's the Life of a Diesel?" Theoretical foundations were then summarized and published in 1963 [15]. The method was used for the preliminary determination lifetime of rail vehicles [11]. The optimum lifetime $T_{\text {opt }}$ is given by:

$T_{\text {opt }}=\sqrt{\frac{2 \cdot H_{0}}{B}}$

Here, $H_{0}$ is the vehicles' acquisition value given as a percentage $=100 \%$ and $B$ is the linear incremental trend coefficient of the maintenance and repair costs. This coefficient is obtained likewise from the charts using linear regression of data. Application of this method is connected with some weaknesses, as discussed below in the results.

\subsection{Vehicle's residual value calculations}

Calculations of the vehicle's residual value according to the Act on Income Tax [13] consider the depreciation period of 5 years in Article 30 within motor vehicles for special purposes, according to the classification in Appendix No. 1 of the Act. Depreciation percentages are fixed for the first year at the level 
of $11 \%$ and for the next four years they are changed to $22.25 \%$. Calculating the relative technical value of the vehicle PTHS in any year of operation is carried out in a percentage of the purchase price, in accordance with the Expert Standard [14], by the equation:

$P T H S=\frac{T H S N \cdot(100-Z A) \cdot(100 \pm T S) \cdot P D S}{10^{6}}$

Initial technical value of the group $T H S N=100 \%$, technical condition changes $T S=0.0 \%$ and the relative group proportion value $P D S=100 \%$ were applied in the equation, in the case of maintained and operational firefighting appliances. Basic amortization $Z A$ [\%] which is calculated as the arithmetic average of the following equation was the only variable in the equation (6):

$Z A=\frac{Z A D+Z A P}{2}$

$Z A D$ parameter is the basic percent reduction during the operation defined in Annex No. 1.4 of the Expert standard [14] and ranges from $20 \%$ in the first year of operation to $90 \%$ in the tenth and following year of operation. ZAP parameter [\%] determines the percentage of the basic reduction for the mileage (see ibid.).

\section{Results}

Overall results of calculations are stated in the following tables and graph exemplifications of which are evident constants and coefficients exponents values used for the calculations in equations (4) and (5).

The difference of calculated results of the vehicle's residual value was set in Figs. 1 and 2, as demonstrated on the case of the vehicle registration number $3 Z 2$ 6957, deployed at the fire station Uhersky Brod. It is evident that the Expert Standard is more suitable for both longer amortization time, and mileage consideration. These factors can significantly affect the vehicle wearing. Expert Standard gives even higher residual value of the particular vehicle in the final outcome.

The difference in resulting functions of repair costs (for the same vehicle) obtained by the method of exponential trends and Brown's method can be seen in Figs. 3 and 4. The vehicle registration number $3 Z 23957$ of the station Uhersky Brod was chosen as an example because due to the highest calculated value of economic life, which is closest to the expected present reality. The appliance was included into exit vehicles on December 31, 2007. Unfortunately, even in these calculations is reflected the fact that operation records were not conducted complexly before 2010 [1 and 2]. Thus, it was found that the vehicle mileage had reached $13,600 \mathrm{~km}$ in years 2008 and 2009 but recorded repair costs had been zero in the same period.
[CZK] The residual value according to the Act on Income Tax, vehicle $3 Z 23957$ in Uhersky Brod

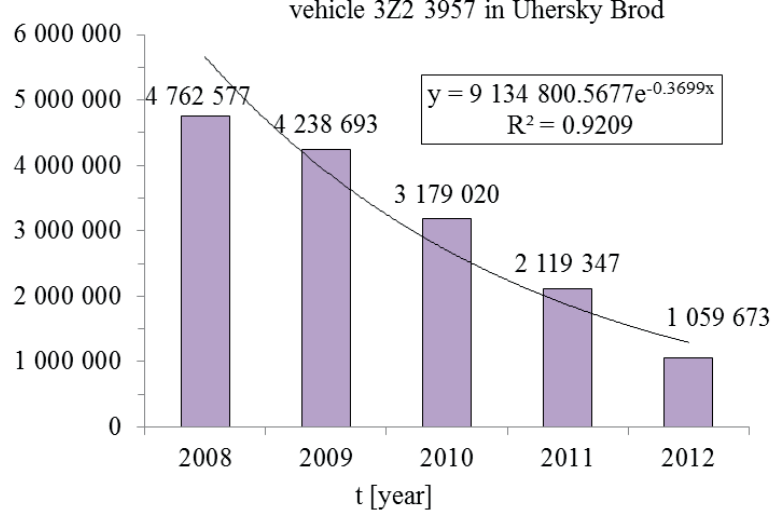

Fig. 1 The residual value according to the Act on Income Tax

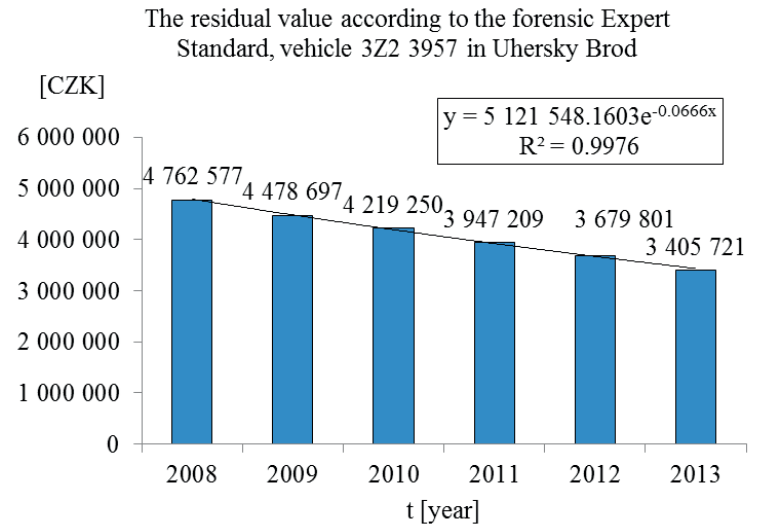

Fig. 2 The residual value according to the forensic Expert Standard

CZK] Total repair cost, vehicle $3 Z 23957$ in Uhersky Brod

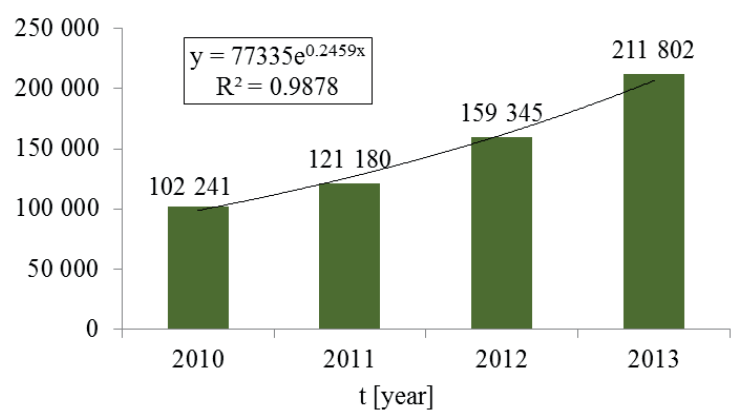

Fig. 3 Total repair costs according to the exponential trends method 


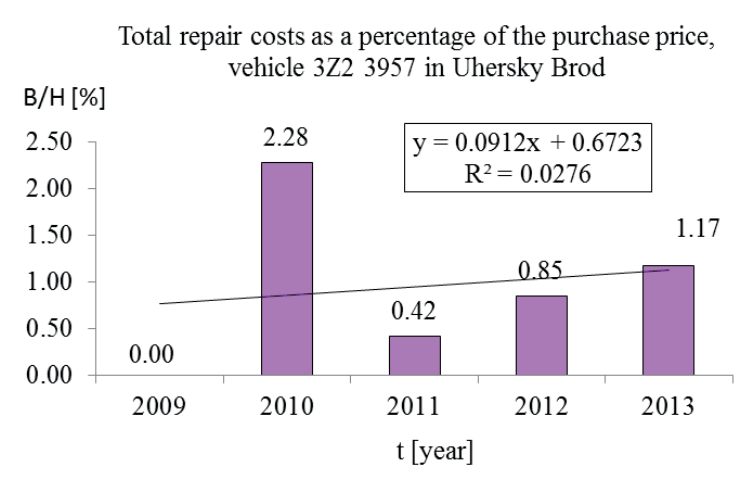

Fig. 4 Repair costs according to the Brown method

Results of the recovery time when depreciating according to the Act on Income Tax are shown in Table 2 [13]. Table 3 presents alternative results of calculations while using the depreciation according to the Expert Standard [14]. Both results are counted when applying the method of exponential trends. As written above next to Figs. 1 and 2, the influence of valuation methods is reflected in the final size of the recovery time.
Results acquired by the Brown method with using linear trends are shown in Table 4. Calculations show that the Brown method application is inappropriate for fire equipment. Calculation results are completely out of reality. Correlation coefficients of each regression curve are very low. The optimal economic life calculations by the equation (5) for negative values of constant $B$ cannot be accomplished thereafter.

Recovery time in accordance with the Brown method Table 4

\begin{tabular}{|l|l|r|r|c|}
\hline Vehicle dislocation & $\begin{array}{c}\text { Registration } \\
\text { mark }\end{array}$ & \multicolumn{1}{|c|}{$B[-]$} & $\begin{array}{c}\text { Correlation } \\
\text { coefficient } R\end{array}$ & $T_{\text {opt } \text { [year] }}$ \\
\hline Zlin & $2 Z 78478$ & 0.2871 & 0.4303 & 26 \\
\hline Zlin & $3 Z 34693$ & -0.0119 & 0.0608 & \\
\hline Slavicin & $3 Z 57550$ & 0.042 & 0.1682 & 69 \\
\hline Otrokovice & $2 Z 78479$ & 0.1074 & 0.1327 & 43 \\
\hline Valasske Mezirici & $2 Z 662647$ & -0.1507 & 0.1503 & \\
\hline Valasske Mezirici & $3 Z 57540$ & 0.0787 & 0.3746 & 50 \\
\hline Valasske Mezirici & $3 Z 34692$ & 0.4995 & 0.7030 & 20 \\
\hline Uhersky Brod & $3 Z 23957$ & 0.0769 & 0.1661 & 51 \\
\hline Uherske Hradiste & $3 Z 66297$ & 0.3754 & 0.9027 & 23 \\
\hline
\end{tabular}

Using this method has its disadvantages. The method was formulated for rail vehicles, which have high initial costs, and the expected optimum life is considerably longer than 10 years. For

Recovery time in accordance with the Act on Income Tax

\begin{tabular}{|c|c|c|c|c|c|c|c|c|}
\hline \multicolumn{8}{|l|}{ ecol } & \multirow{3}{*}{$\begin{array}{c}T_{\text {opt }} \\
\text { [year] }\end{array}$} \\
\hline & & \multicolumn{3}{|c|}{ Maintenance and repairs cost ratio $N_{u}(t)$} & \multicolumn{3}{|c|}{$\begin{array}{c}\text { Residual value of firefighting } \\
\text { appliances in time } N_{p}(t) \text { coefficients }\end{array}$} & \\
\hline Vehicle dislocation & $\begin{array}{c}\text { Registration } \\
\text { mark }\end{array}$ & $A[\mathrm{CZK}]$ & $\beta[-]$ & \begin{tabular}{|c|}
$\begin{array}{c}\text { Correlation } \\
\text { coefficient } R\end{array}$ \\
\end{tabular} & $C[\mathrm{CZK}]$ & $\alpha[-]$ & $\begin{array}{c}\text { Correlation } \\
\text { coefficient } R\end{array}$ & \\
\hline Zlin & $2 Z 78478$ & 36512 & 0.5899 & 0.907 & 8444634 & 0.3699 & 0.960 & 5.2 \\
\hline Zlin & $3 Z 34693$ & 37561 & 0.3529 & 0.961 & 7660778 & 0.3699 & 0.960 & 7.4 \\
\hline Slavicin & $3 Z 57550$ & 27164 & 0.3397 & 0.909 & 8605720 & 0.3699 & 0.960 & 8.2 \\
\hline Otrokovice & $2 Z 78479$ & 64958 & 0.4619 & 0.890 & 8453027 & 0.3699 & 0.960 & 5.6 \\
\hline Valasske Mezirici & $2 Z 62647$ & 32249 & 0.5644 & 0.832 & 7926425 & 0.3699 & 0.960 & 5.4 \\
\hline Valasske Mezirici & $3 Z 57540$ & 4763 & 0.6637 & 0.952 & 8605720 & 0.3699 & 0.960 & 6.7 \\
\hline Valasske Mezirici & $3 Z 34692$ & 3447 & 0.7005 & 0.966 & 7715162 & 0.3699 & 0.960 & 6.6 \\
\hline Uhersky Brod & $3 Z 23957$ & 77335 & 0.2459 & 0.994 & 9134800 & 0.3699 & 0.960 & 8.4 \\
\hline Uherske Hradiste & $3 Z 66297$ & 23196 & 0.5493 & 0.999 & 9134800 & 0.3699 & 0.960 & 6.1 \\
\hline
\end{tabular}

Recovery time in accordance with the Expert Standard

\begin{tabular}{|c|c|c|c|c|c|c|c|c|}
\hline \multirow[b]{2}{*}{ Vehicle dislocation } & \multirow[b]{2}{*}{$\begin{array}{c}\text { Registration } \\
\text { mark }\end{array}$} & \multicolumn{3}{|c|}{ Maintenance and repairs cost ratio $N_{u}(t)$} & \multicolumn{3}{|c|}{$\begin{array}{c}\text { Residual value of firefighting } \\
\text { appliances in time } N_{p}(t) \text { coefficients }\end{array}$} & \multirow{2}{*}{$\begin{array}{c}T_{\text {opt }} \\
\text { [year] }\end{array}$} \\
\hline & & $A[\mathrm{CZK}]$ & $\beta[-]$ & $\begin{array}{c}\text { Correlation } \\
\text { coefficient } R \\
\end{array}$ & $C[\mathrm{CZK}]$ & $\alpha[-]$ & $\begin{array}{c}\text { Correlation } \\
\text { coefficient } R \\
\end{array}$ & \\
\hline Zlin & $2 Z 78478$ & 36512 & 0.5899 & 0.907 & 5553636 & 0.0638 & 0.9982 & 4.3 \\
\hline Zlin & $3 Z 34693$ & 37561 & 0.3529 & 0.961 & 4779616 & 0.0631 & 0.9987 & 7.5 \\
\hline Slavicin & $3 Z 57550$ & 27164 & 0.3397 & 0.909 & 4822246 & 0.0652 & 0.9989 & 8.7 \\
\hline Otrokovice & $2 Z 78479$ & 64958 & 0.4619 & 0.890 & 5565664 & 0.0637 & 0.9980 & 4.7 \\
\hline Valasske Mezirici & $2 Z 62647$ & 32249 & 0.5644 & 0.832 & 5655152 & 0.0704 & 0.9894 & 4.9 \\
\hline Valasske Mezirici & $3 Z 57540$ & 4763 & 0.6637 & 0.952 & 4795414 & 0.063 & 0.9993 & 6.3 \\
\hline Valasske Mezirici & $3 Z 34692$ & 3447 & 0.7005 & 0.966 & 4779616 & 0.0631 & 0.9987 & 6.3 \\
\hline Uhersky Brod & $3 Z 23957$ & 77335 & 0.2459 & 0.994 & 5121548 & 0.0666 & 0.9988 & 9.2 \\
\hline Uherske Hradiste & $3 Z 66297$ & 23196 & 0.5493 & 0.999 & 5095852 & 0.0641 & 0.9996 & 5.3 \\
\hline
\end{tabular}


example, rail kit CityElefant type 471/071/971 costs CZK 217 million within the lifetime of 30 years or rail kit RegioSprinter BR 654 costs CZK 47 million within the lifetime of 25 years. Application of this method assumes steady and in time rising repair costs. To evaluate the lifetime of less costly firefighting equipment, then the results are not those we expected.

\section{Conclusion}

Calculations results show that we can theoretically expect the optimum lifetime close to 9 years operation of firefighting vehicles based on the chassis Renault Midlum. This theoretical aim was achieved without major problems in six of the nine observed trucks. This lifetime depends on the current operational load. The firefighting vehicle lifetime can be prolonged by relocating trucks from the group of emergency vehicles to reserves that are in lower service load. Using the Expert Standard for more accurate and more realistic residual vehicle value determination than using the Act on Income Tax is the next recommendation. Confirmation of the Brown method unsuitability for these calculations is the last major finding.

\section{Acknowledgements}

This paper was supported by an internal grant of specific research "SP2014/44 - Determining aspects of operational and functional reliability of firefighting equipment."

\section{References}

[1] JANOSIK, L.: Evaluation of Fire Appliances on Renault Midlum chassis with Brigades of Fire and Rescue Service of the Zlin region. Fire Protection 2014, Ostrava : Association of Fire and Safety Engineering, 2014, ISBN 978-80-7385-148-4, 108-111.

[2] MONOSI, M., JANOSIK, L.: An Essay of Firefighting Vehicles' Reliability. Production Management and Engineering Sciences: Proc. of the Intern. Conference on Engineering Science and Production Management, London : CRC Press, 2016, ISBN: 978-1-13802856-2, 201-206.

[3] JANOSIK, L.: Functional Reliability of Operation of Selected Firefighting Vehicles (in Czech), PhD. thesis, Ostrava : VSB-Technical university of Ostrava, 2015, $142 \mathrm{p}$.

[4] MONOSI, M., SLOBODA, A., PALUCH, B., HAJDUOVA, Z.: Fire Equipment (in Slovak), EDIS : University of Zilina, 2013, ISBN 978-80-554-0705-0, $402 \mathrm{p}$.

[5] BALCAREK, V.: Personal Consultation and Operational Data Export from IKIS II (in Czech). Fire Rescue Service of Zlin Region : Regional Directorate Zlin, Prirucka 213, December 2013.

[6] CSN IEC 50(191) - International Electrotechnical Vocabulary. Chapter 191: Dependability and Quality of Service (in Czech), Praha : Czech office for Standards, Metrology and Testing, 1993, $166 \mathrm{p}$.

[7] STODOLA, J.: Operational Reliability and Diagnostics (in Slovak), Brno : University of Defence, 2002, 88 p.

[8] SPACILOVA, L., JANOSIKOVA, I., HON, M.: Microeconomics B. Workbook, $1^{\text {st }}$ ed. (in Czech). Ostrava : Faculty of Economics : VSB-Technical University, 2014 vol. 19, ISBN 978-80-248-3608-9, 121 p.

[9] JURECKA, V., JANOSIKOVA, I. Microeconomics. Textbook for Bachelor Studies, $1^{\text {st }}$ ed. (in Czech). Ostrava : Faculty of Economics : VSB-Technical University, 2005, ISBN 978-80-248-0910-6, 315 p.

[10] Instructed the Director General of the Fire and Rescue Service and the Deputy Minister of Interior of 13. 3. 2006 issued Order Machinery Fire Rescue Services of the Czech Republic (in Czech). Praha : The collection of internal management Director General of Fire Rescue Service of the Czech Republic and the Deputy Minister of the Interior, 2006, No. 9, 28 p.

[11] DANEK, A., SIROKY, J.: Theory of Replacement of Conveying Vehicles (in Czech), Ostrava : VSB-Technical University, 1999, ISBN 80-7078-568-3, $156 \mathrm{p}$.

[12] HOLUB, R., VINTR, Z.: Fundamentals of Reliability (in Czech). Brno : University of Defence, 2002, 174 p.

[13] Czech National Council Act No. 586/1992 Coll., On income taxes, as amended (in Czech). Collection of Acts, 1992, part 117, 48 p.

[14] KREJCIR, P., BRADAC, A.: Expert standard No. I / 2005 - Valuation of Motor Vehicles (in Czech). Brno : Academic publishing CERM Ltd., 2005, $103 \mathrm{p}$.

[15] BROWN, R. G.: Smoothing Forecasting and Prediction of Discrete Time Series. Englewood Cliffs : NJ : Prentice-Hall Inc., 1963,464 p. 